\title{
SOCIAL FORESTRY - A CASE STUDY OF THE DISTRICT OF NORTH
} 24-PARGANAS IN WEST BENGAL

*1 Bappaditya Sahoo

*1 Jogamaya Devi College, 92, S P Mukherjee Road, Kolkata - 700026, University Of Calcutta, INDIA

Abstract:

Social Forestry now become a common work for all government in all civilized country. Its effects found not only on human being but also on every section of the society. Government should take necessary actions to do success social forestry programme. This programme not only provide food, fodder, shelter for people but also a bulk amount of revenue to the government. Social forestry also effects on the climatic condition of the local area. Social forestry boost up the socio-economic condition of the country. It has great impact on national and international status. People play an important role to success social forestry.

Keywords:

Social forestry, revenue and economic development, employment opportunities, increase national growth, industry explore

Cite This Article: Bappaditya Sahoo, "SOCIAL FORESTRY - A CASE STUDY OF THE DISTRICT OF NORTH 24-PARGANAS IN WEST BENGAL" International Journal of Research - Granthaalayah, Vol. 3, No. 6(2015): 73-83.

\section{INTRODUCTION}

In modern India during the sixth Five Year Plan period which covered the first half of the 1980s approximately Rs. 10 billion (one thousand crore) or nearly US\$ 1 billion was spent on social forestry activities. This figure is expected to double during the Seventh Five Year Plan (1985 90) with funds provided by the Government of India, State Governments, bilateral and multilateral donors, private industries and individuals. The term social forestry is difficult to define precisely, but is generally understood to mean tree-growing (including associated products, e.g. bamboo, grasses, legumes) for the purpose of rural development. As social forestry has a rural development focus and is heavily dependent on the active participation of people, it is also known as "forestry for local community development" or "participatory forestry". An up to date and comprehensive discussion of these terms and the role of social forestry in rural development is to be found in Tree Growing by Rural People, FAO Forestry Paper, 64, 1985. Although a wide range of activities are included in social forestry. 


\section{INTERNATIONAL JOURNAL of RESEARCH -GRANTHAALAYAH

\section{ABOUT THE NORTH 24-PARGANAS}

West Bengal is one of the important states in India, situated the eastern parts of the country and is one of the banks of the Bay of Bengal. The state of West Bengal consists of 19 districts and North 24 parganas in one of them.

\section{GEOGRAPHICAL LOCATION}

North 24- parganas derives its name number of revenue districts to the British East India Company in 1757 by the Nawab of Bengal. North 24 parganas had emerged as a separate district on the day of March 1986, bifurcating the erstwhile 24 parganas district. It lies between 22,11,6 and 23,1,2 north latitude sand between 88,20 and 5 east parganas .this is bounded by Nadia district and Bangladesh in the east and cover an area of 4094sq.km. The census of 2001 records a total population of 8930295 persons of which $52.4 \%$ are males and $47.57 \%$ are females .Of the total population the percentage of scheduled caste ,schedule tribes, literates, works and urbanites are 22.44,7.88,28.17 and 51.32.

\section{ADMINISTRATIVE SET UP}

The districts incorporates 5 sub-division, 22community development blocks and 33 police stations. The panchayat set up comprises 1 zilla parishad, 22 panchayat samities and 200 greams panghayat, there are61 towns of different categories. Barasat town is the district headquarters.

\section{RIVERS}

The district is traversed by a number of moribund rivers which were primarily spilling cannels of the river Bhagirathi. The Hoogly, Ichhamati, Raimangal, Jamuna, Vidyadhari, and kalindi are his important river which are, mostly tidal in nature and not fed by upstream flow of water discharge, thereby leading to gradual degradation of river regime in the district.

\section{SOIL}

In the district of North 24 parganas soil is mostly new alluvium except in the southern part where it is saline .It varies from sandy to clay loams, but sandy loams are predominant. The water level is $0.6 \mathrm{~m}$ to $8.9 \mathrm{~m}$ below the ground surface. There is no mineral or rock deposits reported within the district. However, earth for brick making purpose in readily available along the river channels.

\section{CLIMATE}

In general, the climate of West Bengal varies from sub humid to per humid with uniformity of temperature. The Tropic of Cancer runs across the middle of Nodia, Burdwan, Northern parts of 


\section{INTERNATIONAL JOURNAL of RESEARCH -GRANTHAALAYAH

Bankura and Purulia districts. Inspite of position in Equatorial zone, the Himalayan Mountains in the North, Bay of Bengal in the south and extensive network of rivers cannals tanks etc. Do not allow extreme climatic conditions of prevail in the state.

The location of north 24 parganas clearly implies as subtropical climate with monsoonal regime. The mean annual maximum and minimum temperature are $40^{\circ} \mathrm{c}$ and $10^{\circ} \mathrm{c}$ respectively, the mean annual rainfall is $1759 \mathrm{~mm}$.

\section{SOWN AREA}

In West Bengal the percentage of net sown areas is higher (above 70\%) in Uttar and Dakshin Dinajpur, Nadia, Murshidabad, Cooch Beher, Hoogli, Burdwan and Birbhum Districts.High percentage of forest cover exist in the district having hills and mountain ranges and also in the coastal areas protected forests also cover-considerable area in Purulia ,Bankura ,Medinipur ,Burdwean and BIrbhum districts .The maximum area under forest $(44.68 \%)$ is found in Darjeeling district.

In the district of north 24 parganas the net sown area is about 57.92\% while current fellow and other fellow constitute $0.30 \%$ of the total area. Forest is only $0.1 \%$ inclusive of both reserve and protected forest. About $55 \%$ of the sown area is irrigated. Since the district is rich in underground resource, deep tube wells and shallow tube wells contribute more than $98 \%$ of the irrigation area in the southern part is less in comparison in the north.

\section{CROPS}

Rice is the most dominant crop and occupies about $62.31 \%$ of grass cropped produced .Besides these ,pulses (3.5\%), oil seeds (7.11\%),jute, vegetables, wheat and sugarcane are grown considerably.

\section{INDUSTRIES}

The traditional large and medium scale industries in the district are mainly located in Barrackpore industrial area .The main industrial products are jute, cotton textile, engineering, food product, silk and rubber. A new industrial belt is being set up at Barasat, Madhamgram, Rajarhat, Bongaon, Basirhat and Salt Lake.

\section{ROADS}

The districts has about $6823 \mathrm{~km}$.of metaled roads of which national highway no. 34 and 35 serve $101.9 \mathrm{~km}$ and state highways $54.2 \mathrm{~km}$. The length of Railway in the district of about $181 \mathrm{~km}$. The metro railway situated at Dumdum. There are number of ferry services in the district .Ferry across the river is very important and indispensable particularly in the southern part of this 


\section{INTERNATIONAL JOURNAL of RESEARCH -GRANTHAALAYAH \\ A knowledge Repository}

Social

district. Basirhat sub-division, the most part of it, depends upon ferry services .The boats ply on the river Ichhmati, Jamuna, Raimangal and Kalindi etc.

\section{POPULATION}

Some important information relating to the population of north 24 parganas district as well as West Bengal reveals the following figures of populations including bengalee in the West Bengal and North and South 24 Parganas .Table no 1 shows the population in West Bengal and North and South 24 parganas.

Table 1: Population in west Bengal and north \& south 24 parganas

\begin{tabular}{|l|l|l|l|}
\hline & Population in 1991 & Population in 2001 & Population in 2011 \\
\hline West Bengal & $6,80,77,965$ & $8,02,21,17$ & $9,12,76,115$ \\
\hline \multirow{2}{*}{ North 24 pgs } & $\begin{array}{l}72,81,881 \\
(10.70 \%)\end{array}$ & $\begin{array}{l}89,30,295 \\
(11.79 \%)\end{array}$ & $\begin{array}{l}1,00,09,781 \\
(10.97 \%)\end{array}$ \\
\hline South 24 pgs & $\begin{array}{l}57,15,030 \\
(8.39 \%)\end{array}$ & $\begin{array}{l}69,09,015 \\
(8.61 \%)\end{array}$ & $\begin{array}{l}81,61,961 \\
(8.94 \%)\end{array}$ \\
\hline
\end{tabular}

Source: West Bengal State Forest Report

\section{OBJECTIVES OF THE STUDY}

Keeping in view the growing development of social forestry for supplying food, fodder, firewood, raw material, etc. Arrangement should be made for adequate supply of these items. It requires scientific analysis of the problem so that the resources available from forestry can be utilized efficiently. The other important points to be consider is the livelihood hood of the poor community who lives surroundings the forest, the poorest if the poor people.

The other points is that afforestation the landless labor the small farmers and other village artistians, who hardly get sufficient work during the year, will get employment right.

The primary objective of the research is to make a study of the impact of social forestry in West Bengal with special reference to the district of north 24- parganas. For this purpose the study specially aims act:

a) To study the overall objectives of the social forestry.

b) To study the various components of social forestry.

c) To study the several important issue to the programme. 


\section{INTERNATIONAL JOURNAL of RESEARCH -GRANTHAALAYAH \\ A knowledge Repository}

Social

d) To study the achievements under the programme.

e) To find out the various problems.

f) To study the steps taken by the government for solving the problems.

g) To suggest ways for improving the implementations of the programme for better result.

\section{PERFORMANCE OF SOCIAL FORESTRY PROGRAMME}

There are five subdivision in the district of north 24 parganas of which 3 sub division ,namely Barasat, Barrackpore and Basirhat have been studied and a survey report of the social forestry in these subdivision have been prepared from 2009-2014 which is presented below in the tabular format.

Table 2: Survey report in Barasat, Barrackpore and Basirhat Subdividion in 2009

\begin{tabular}{|l|l|l|l|l|l|l|}
\hline \multirow{2}{*}{ Year } & \multicolumn{6}{|l|}{2009} \\
\cline { 2 - 7 } & $\begin{array}{l}\text { Sub- } \\
\text { division }\end{array}$ & Beat & P.S & G.P & Location & Area \\
\hline Barasat & Barasat & Barasat & Deganga & Deganga-1 & $\begin{array}{l}\text { Bidyadhari } \\
\text { riverbank }\end{array}$ & 15 ha. \\
\hline Barrackpore & Barrackpore & $\begin{array}{l}\text { Barrackpore- } \\
\text { I }\end{array}$ & $\begin{array}{l}\text { Barrackpore- } \\
\text { II }\end{array}$ & Midnapore & $\begin{array}{l}\text { Barrackpore } \\
\text { Military } \\
\text { camp }\end{array}$ & 50 ha. \\
\hline Basirhat & Basirhat & Baduria & Swarupnagar & Charghat & $\begin{array}{l}\text { High } \\
\text { embankment } \\
\text { of Icchamati }\end{array}$ & 10 ha. \\
\hline
\end{tabular}

In the table 2 , survey report states that social forestry has been done in the Barasat, Barrackpore and Basirhat subdivision ,covering landed area measuring 15 ha.(In Bidyadhari river bank), 50 ha. (Barrackpore Military camp), and 10 ha. (In high embankment of Ichhamati river), respectively .However, the survey report reveals that potential of covering another $15 \mathrm{ha}$. Of area in Basirhat could not be achieved because of the damage done by the brakish water caused by Aila and no plantation could be done.

Table.3: Survey report in Barasat, Barrackporee and Basirhat Sub division in 2010

\begin{tabular}{|l|l|l|l|l|l|l|}
\hline \multirow{3}{*}{ Year } & \multicolumn{2}{|l|}{2010} \\
Range & $\begin{array}{l}\text { Sub- } \\
\text { division }\end{array}$ & Beat & P.S & G.P & Location & Area \\
\hline Barasat & Barasat & Habra & Barasat-I & Taraberia & Rajberia & 8 ha. \\
\hline
\end{tabular}


INTERNATIONAL JOURNAL of RESEARCH -GRANTHAALAYAH

A knowledge Repository

Social

\begin{tabular}{|l|l|l|l|l|l|l|}
\hline Barrackpore & Barrackpore & $\begin{array}{l}\text { Barrackpore- } \\
\text { I }\end{array}$ & $\begin{array}{l}\text { Barrackpore- } \\
\text { I }\end{array}$ & Majhipara & $\begin{array}{l}\text { Naihati-road } \\
\text { Kanchrapara } \\
\text { Military } \\
\text { Area }\end{array}$ & 15 ha. \\
\hline Basirhat & Basirhat & Basirhat & Swarupnagar & $\begin{array}{l}\text { Charghat } \\
\text { Sarapur }\end{array}$ & $\begin{array}{l}\text { Icchamati } \\
\text { River side }\end{array}$ & 20 ha. \\
\hline
\end{tabular}

In the table 3 , survey report states that social forestry has been done in the Barasat ,Barrackpore and Basirhat sub division, covering landed area measuring 8 ha.(In Rajberia -Naihati road), 15 ha.(In Kanchrapara military area) and 20ha. (In Ichhamati river side). Respectively.

Table 4: Survey report in Barasat, Barrackpore and Basirhat sub-division in 2011

\begin{tabular}{|c|c|c|c|c|c|c|}
\hline \multirow{2}{*}{$\begin{array}{l}\text { Year } \\
\text { Range }\end{array}$} & \multicolumn{6}{|l|}{2011} \\
\hline & $\begin{array}{l}\text { Sub- } \\
\text { division }\end{array}$ & Beat & P.S & G.P & Location & Area \\
\hline Barasat & Barasat & Habra & Barasat-II & $\begin{array}{l}\text { Asokenagar } \\
\text { Kalyangar }\end{array}$ & $\begin{array}{l}\text { Asokenagar } \\
\text { Kalyangar } \\
\text { municipality } \\
\text { area. }\end{array}$ & $\begin{array}{l}8 \\
\text { ha. }\end{array}$ \\
\hline $\begin{array}{l}\text { Barrackpor } \\
\text { e }\end{array}$ & $\begin{array}{l}\text { Barrackpor } \\
\text { e }\end{array}$ & $\begin{array}{l}\text { Barrackpore } \\
\text {-II }\end{array}$ & $\begin{array}{l}\text { Barrackpore } \\
\text {-II }\end{array}$ & $\begin{array}{l}\text { Bilkanandi } \\
\text { and II }\end{array}$ & $\begin{array}{l}\text { Jafarpur } \\
\text { Military Area }\end{array}$ & $\begin{array}{l}15 \\
\text { ha. }\end{array}$ \\
\hline Basirhat & Basirhat & Baduria & Baduria & $\begin{array}{l}\text { Satyaeshyanaga } \\
\mathrm{r} \text { and } \\
\text { Swarupnagar }\end{array}$ & $\begin{array}{l}\text { Sangrampur } \\
\text { Banglani } \\
\text { Road side }\end{array}$ & $\begin{array}{l}20 \\
\text { ha. }\end{array}$ \\
\hline
\end{tabular}

In the table 4, survey report states the social forestry has been done in the Barast, Barrackpore and Basirhat Subdivision, covering a landed measuring 15 ha. (In asokenagar kalyannagar municipality area), 20 ha. (In Jafarpur military firing range area) and 15 ha. (Sangrampur banglani road side), respectively.

Table 5: Survey report in Barasat, Barrackpore and Basirhat Sub-division in 2012

\begin{tabular}{|l|l|l|l|l|l|l|}
\hline \multirow{2}{*}{ Year } & \multicolumn{5}{|l|}{2012} \\
\cline { 2 - 3 } & Sub-division & Beat & P.S & G.P & Location & Area \\
\hline
\end{tabular}




\begin{tabular}{|l|l|l|l|l|l|l|}
\hline Barasat & Barasat & Barasat-II & Barasat-III & Kirtipur & Bilchanpur & 5 ha. \\
\hline Barrackpore & Barrackpore & $\begin{array}{l}\text { Barrackpore- } \\
\text { II }\end{array}$ & $\begin{array}{l}\text { Barrackpore- } \\
\text { III }\end{array}$ & $\begin{array}{l}\text { Patua } \\
\text { bandip }\end{array}$ & $\begin{array}{l}\text { Dumdum } \\
\text { Barrackpor } \\
\text { Exp.way }\end{array}$ & $\begin{array}{l}10 \\
\text { ha. }\end{array}$ \\
\hline
\end{tabular}

In the table 5, survey report states that in the Barasat, Barrackpore and Basirhat subdivision, social forestry has been done in the landed area measuring 5 ha. (In Nalta Khalpar), 10 ha. (In Noai Khalpar) and 10 ha. (In Indo-Bangladesh road), respectively.

Table 6: Survey report in Barasat, Barrackpore and Basirhat sub-division in 2013

\begin{tabular}{|c|c|c|c|c|c|c|}
\hline \multirow{2}{*}{$\begin{array}{l}\text { Year } \\
\text { Range }\end{array}$} & \multicolumn{6}{|l|}{2013} \\
\hline & Sub-division & Beat & P.S & G.P & Location & Area \\
\hline Barasat & Barasat & Barasat-I & Barasat-II & Kirtipur & Bilchandipur & 5 ha. \\
\hline Barrackpore & Barrackpore & Barrackpore & Barrackpore & $\begin{array}{l}\text { Patua } \\
\text { Bandipur }\end{array}$ & $\begin{array}{l}\text { Dumdum } \\
\text { Barracpore }\end{array}$ & $\begin{array}{l}10 \\
\text { ha. }\end{array}$ \\
\hline
\end{tabular}

In the table 6, survey report states that social forestry has been done in the Barasat and Barrackpore subdivision, the landed area measuring 5 ha. (In Bilchandapur) and 10 ha. (In Dumdum Barrackpore exp.Way), respectively. No social forestry could be done in Basirhat subdivision in 2013 due to the entry of brackish water caused by the Tsunami which occurred in December, 2012.

Table 7: Survey in Barasat and Basirhat sub-division in 2014

\begin{tabular}{|c|c|c|c|c|c|c|}
\hline \multirow{2}{*}{$\begin{array}{l}\text { Year } \\
\text { Range }\end{array}$} & \multicolumn{6}{|l|}{2014} \\
\hline & Sub-division & Beat & P.S & G.P & Location & Area \\
\hline Barasat & Barasat & Habra & Amdanga & Amdanga & $\begin{array}{l}\text { Amdanga } \\
\text { roadside }\end{array}$ & 5 ha. \\
\hline
\end{tabular}




\section{INTERNATIONAL JOURNAL of RESEARCH -GRANTHAALAYAH

\begin{tabular}{|l|l|l|l|l|l|l|}
\hline Basirhat & Basirhat & Basirhat & Swarupnagar & koiluri & $\begin{array}{l}\text { High } \\
\text { Embankment } \\
\text { of Jamuna }\end{array}$ & 10 ha. \\
\hline
\end{tabular}

In the table 7, survey reports states that social forestry has been done in the Barasat and Basirhat subdivision, covering landed area measuring 5 ha. (In Amdanga raod side) 10 ha. (In High embankment of Jamuna river), respectively .No afforestation could be done in Barrackpore subdivision in 2014 as the designated site was Barrackpore military camp area and legal permission was granted by the military official in due time.

In the above mentioned areas, the main handicaps in performing social forestry are as follows:

(i) Low fund allocation from district forest office (DFO), Zilla parishads

(ii) Shortage of manpower and public awareness to look after the work from panchayat level.

As a result, the straying cattle is damaging the crops and plants.

\section{MAJOR PROBLEMS}

1. In 16 selected division the social forestry programme was implemented by the regular officials of the forest Department in addition to their normal workload without any extra staff support. However, in few cases staff was sanctioned for implemented of specific schemes.

2. No extension and motivated staff at the grass root level was appointed in forest office in some cases posts are filled up partially.

3. The officials at various levels involved in the programme were not trained in social forestry and there was no permanent arrangement for their training .It was also forest observed that the forest department official did not prefer their posting in social Forestry Organization.

4. The implementation of the programme was affected in some of the cases due to lack of coordination between the forest departments and block agencies. No follow up action taken up by the implementing agencies in almost all cases for getting feedback on implementation through regular fields visits.

5. The size of some selected nurseries was very small, whereas they were required to cover a very wide areas in terms of number of villages, some of the selected nurseries covering more than 100 villages each had also work much below capacity.

6. In some of the cases, the beneficiaries under Farm Forestry were in fact big farmers whereas the programme was meant for small marginal farmers.

7. In actual seeding distribution was reported to be more than what was targeted for.

8. Sometimes funds were sanctioned in time whereas in most cases the programme suffered due to late release of fund but the District Rural Development Agencies (DRDA) under social forestry components of National Rural Employments Programme (NREP), Drought Prone area Programme (DPAP) etc.

9. Involvement of voluntary agencies in Social Forestry Programme appeared to be nominal and undoubtedly is a great problem. 


\section{INTERNATIONAL JOURNAL of RESEARCH -GRANTHAALAYAH

10. Strip plantation on public land had yet matures in our state .Some informal arrangements had, however been made in a few districts for sharing of the produce public plantation as and when matured.

11. Out of 200 villages, blocks plantation on public community land were raised in 23 villages only which proves the lack of proper administrative policy.

12. More and more selected beneficiaries reported lowers survival percentage of the seeding due to scarcity of water, browsing of plants by animals, an attack from insects and pests.

13. There was no remarkable achievement in the major source of fuelwood, fodder and small timber for the beneficiaries as they had to travel long distance for collection of fuelwood and fodder.

14. Wages paid under social forestry programme were less than the minimum wages under the Act.

15. Smuggling activities in forest affect the social forestry.

\section{DISCUSSION AND CONCLUSION}

The primary object of the present field work has been to make a study on the problems of social forestry in West Bengal through a case study in the district of North 24 parganas. As the problems are closely linked with various sectors, the study has made an attempt to identify many such problems that have ultimately lead to the financial foresters and the people live surrounding the forest Government has been trying to resolve these problems so that income of poor and community will increase and to improve the economic condition of that people.

Social forestry plays a pivotal role in national economy .Its potential as foods supplier, fuel wood, fodder, capacity to generate employment an improve national economy thought export earning was not realized earlier.After Independence, special emphasis was given to forest department. It is very difficult to achieve socio economic development of poor man community, provide rural employment and derive financial strength through earning foreign exchange to achieve this goal appropriate measures on the part of government may be taken update national policy.

The study reveals that social forestry suffers from many problems. To overcome most of the problems and for development of social forestry in West Bengal as well as North 24 parganas, some suggestion are put forward:-

- Afforestation to be made in abandoned Jhum lands and mind areas, and also utilized land under state government or private ownership for creating green belts environments.

- Linear strip plantation of fast growing species on side of public roads, river banks, irrigation, cannels, etc.

- Implementation of farm forestry programme may be made in the form of rising rows of trees on boundaries of fields and also flowering tree and shrubs mainly to serve as recreation forest for the Urban and rural pollution. 


\section{INTERNATIONAL JOURNAL of RESEARCH -GRANTHAALAYAH

- $\quad$ To encourage peoples participation involving women and young people in conservation of forest and environment

- To create environmental awareness celebration of "Vana Mahotsava", "Environment day ", additional ,monitoring incentives may be considered for the official for the proper motivations of staff posted in the social forestry organization. In order to give a thrust to social forestry separate trained staff should be provided at all levels including extension and motivation staff at the gross route level.

- $\quad$ Proper training arrangement should be there at all levels of staff.

- The supply of seedlings should be at minimum price in order to prevent the wastage of the same the seeding to small marginal farmers may be supplied up to a certain limit and beyond that limit supply should be priced.

- $\quad$ There is need for setting up a fore more nurseries in rural areas for wider coverage. For quick and large scale multiplication of seedlings without any impairment in quality, technology innovations should be encouraged.

- $\quad$ Fund for rising of seedlings in the nurseries should be made available well in time and also be sufficient.

- The voluntary organization should be strongly associated with the implementation of the program .However, the capabilities of dynamic voluntary organizations should be assists in advance, and they may be encouraged to adopt a group of village for free plantation programme.

- $\quad$ There should be an integrated approach involving all concerned departments related to forest of Coordinated action for successful implementation of social forestry. Targets setting under various components of the programme should be the responsibility of district level committee .The programme at the grass roots should be implemented through block and gram panchayat level committee with peoples participations at all levels.

- Incentives in the form of fertilizers and insecticides should also be distributed free to small marginal farmers and weaker section of the society.

- The system of maintenance of records especially distribution of seedlings etc. needed to be considerably improved.

- $\quad$ Seedlings should be made available at the plantation sides for which more nurseries should be set -up.

- Unrestricted grazing of animal should be regulated in the village under the supervision of local panchayet.

- $\quad$ Fund should be increased in the government budget for the social forestry programme.

\section{REFERENCES}

[1] S.P. Singh, "Forestry land Evaluation" 1990, Surya Publication, Dehra Dun.

[2] Akhileshwar Pathak, "Contested Domains" 1994, Sage Publication Ltd. New Delhi.

[3] T.V Sairam,"fiocal Policy and Environment", 1986, Agan Prakshan, Delhi.

[4] S.S. Negi,"Forest for Socio-Economic", and Rural Development in India”, 1996, Indus Publications, New Delhi.

[5] V. Shiva, "Ecology and the Politics at Survival", 1991, United Nations University Press. 


\section{INTERNATIONAL JOURNAL of RESEARCH -GRANTHAALAYAH

Social

[6] H.D. Kumar,"Forest Resources Conservation and Management,"2001, Affiliated East West Press Pvt. Ltd., New Delhi.

[7] G. A. Baston, "Empire Forestry and the origins of Environmentalism,"2002, Cambridge University Press, U.K.

[8] H .Rangan, "of Myths and Movments", 2000, Oxford University Press, New Delhi.

[9] C. Martin, "the Rainforest of West Africa", 1991, Biskhouser Verlage, Switzerland.

[10] J.G. Hawkes," Conservation and Agriculture", 1978, Gerald Duckworth \& Co. Ltd., London.

[11] M.L. Ross, "Timber Booms and Institutions Breakdown in South East Asta”, 2001, Cambridge Univ. Press, U.K.

[12] A.S Gulera, "Production Consumption and Trade of Forest Production in India", 1990, International Book Distributions, Dehradun.

[13] Gerald and Robin, "Beyond the Woodfuel Crisis", 1988, Earthscan Publication Ltd., London. 